\title{
2
}

\section{Australia in the global dynamics of social science: De-centring Europe and de-mythologising the 'Asian Century'}

Raewyn Connell

\section{Introduction}

This chapter addresses two major challenges facing the social sciences in Australia. The first is the situation of Australian social science in a world context, which must be considered in the light of the postcolonial thinking that is now developing in all the social sciences worldwide. The challenge is all the greater because, in Australia, that reconsideration is taking place in institutions situated on the dispossessed land of Australia's Indigenous peoples. The second challenge is that this reconsideration is occurring in the context of the promotion of government plans for Australian capitalists to exploit what are seen as the vast growing markets of Asia, under the rubric of the Asian Century'. In this chapter, I will discuss both agendas, and the contradiction between them. ${ }^{1}$ I will also argue that the engagement with social science in the

1 Indeed, the Academy of the Social Sciences in Australia's Annual Symposium on 'The Social Sciences in the Asian Century', from which this book arose, reflected these two strikingly different agendas. 
Asia-Pacific region needs to be seen in the broader context of a global economy of knowledge, including the history of colonialism and the development of neoliberal economics.

\section{The global economy of knowledge}

In the social sciences, we usually work with the convenient fiction that the disciplines we work in, and the concepts we work with, do not come from anywhere in particular. They are just 'in the air', so to speak. When we cite a particular author or study - 'Smith, Jones and Robinson 2009' — we rarely stop to think what ethnic group Smith comes from, to whom Jones is married or what untenured job Robinson is currently holding. Indeed, the most influential epistemological viewpoint in the social sciences tells us that these details do not matter, that the more abstract and decontextualised the knowledge, the better it is, and the more scientific. Even highly context-focused social sciences, like history and anthropology, tend to see their methodology in this way.

There is, however, a counter-current of thought in social science that has never been persuaded that decontextual is good; arguing, indeed, that social determinations shape all intellectual work-and not superficially but at the most profound level. This thinking has nineteenth-century roots but was stated with great brilliance by Gyorgy Lukács in History and class consciousness (1971), originally published in 1923 and rapidly suppressed by authoritarian regimes on both the right and the left. His ideas were taken up by Karl Mannheim in his 1929 masterpiece Ideology and utopia (1985), and turned into the sociology of knowledge. In a later generation, Michel Foucault's immensely influential work on cultural history showed how systems of knowledge were not only embedded in social power but themselves functioned as techniques of power and social control (Foucault 1977). At much the same time, studies of the impact of gender relations on knowledge formation were developed by scholars such as Dorothy Smith (1990) and became known as standpoint epistemology. The more recent development of critical whiteness studies has begun to do the same kind of job for race relations.

These developments, important as they have been, were nevertheless focused on the societies of the global North, the imperial powers of Europe and North America that in a postcolonial era remained the centre of the global capitalist economy. In the past generation, the relation of global power structures to the making of knowledge systems has finally come under close scrutiny. A decisive step occurred with the publication of Edward Said's Orientalism (1978), which examined the construction of European knowledge about the Arab world and the 'East' in the context of European world power. Said's work, together with 
other contributions - of which perhaps the most important was the work of the Subaltern Studies group leading up to Dipesh Chakrabarty's Provincializing Europe (2000) - opened up a broad set of issues that have come to be called 'postcolonial studies' in the humanities.

This is the territory now being explored by social scientists in a vigorous literature on the global dynamics of knowledge. The strands of this literature include research on alternative traditions in social science (Alatas 2006; Patel 2010), southern theory (Connell 2007; Meekosha 2011), postcolonial sociology (Bhambra 2007; Reuter and Villa 2010), indigenous knowledge (Odora Hoppers 2002), the psychology of liberation (Montero 2007), decolonial thought (Mignolo 2005; Quijano 2000), the decolonisation of methodology (Smith 2012) and more.

For our present discussion, the most important resource is the global sociology of knowledge developed by the Beninese philosopher Paulin Hountondji in Endogenous knowledge (1997; see also Connell 2011). Hountondji identifies the problem not as the simple imposition of Western perspectives, but as a global division of labour in the realm of knowledge, with its roots in imperialism. The colonial world served as a rich source of data for science; figures as famous as Charles Darwin and Alexander von Humboldt shared in the collecting. The data were shipped back to the metropole - that is, the imperial centre-which became the site of the theoretical moment in knowledge production. Data were classified and intellectual structures built and debated in the universities, museums, botanic gardens, scientific associations and research institutes of the imperial powers. Here, specialised workforces were created, and practical fields were transformed into applied sciences such as engineering, agronomy and medicine. In this form, science was returned to the periphery, and applied by colonial powers in the mines, in agriculture and in government.

In the contemporary world, the periphery continues to be a rich source of raw materials for the new biology, pharmaceuticals, astronomy, social science, linguistics, archaeology and more. The metropole continues to be the main site of theoretical processing, now including corporate research institutes and giant databanks. Intellectual workers in the periphery are pushed towards a stance Hountondji calls 'extraversion' - a key concept.

To function successfully as a scientist in the periphery-whether in Africa, China or Australia - one must read the leading journals published in the metropole, learn the research techniques taught there and gain recognition there. Career paths include advanced training in the metropole, attending conferences in the metropole and, for the more successful, getting a job in the metropole. The theoretical frameworks developed in the metropole become embedded in 
the intellectual work of the periphery, not by the exercise of direct control, but by the way the whole economy of knowledge is organised, and the extraversion this economy requires.

It is not hard to see this economy of knowledge at work in social science. The foundation stories of our disciplines are told with heroic figures from Europe at the centre: Adam Smith, Leopold von Ranke, Karl Marx, Max Weber, and so on. With very few exceptions, the theorists of Europe and North America are the ones who still provide our paradigms: Michel Foucault, Howard Becker, Jürgen Habermas, Gilles Deleuze, Pierre Bourdieu, Judith Butler, and so on. Most journals in the social sciences are published in the global North, and all of the most prestigious ones. Output in the global South is marked by extraversion: in Brazil, South Africa, Colombia, New Zealand, Australia or China, the usual structure of papers in a local journal is hybrid, consisting of a theoretical discussion derived from Europe and North America, plus data derived locally. There is a steady traffic of social scientists going to the North to study for doctorates, to work on sabbatical or to seek jobs.

To acknowledge the global economy of knowledge is surprisingly difficult, though the data are very clear. Many social scientists do not like to be told this; many careers are deeply invested in the current Northern paradigms. Within the dominant conventions of our disciplines, the works of Foucault, Habermas, Deleuze, Bourdieu, and so on are simply 'theory'; they are not read as specifically European ideas arising from the social experience of the global North. Social scientists, like natural scientists, often think they are part of a search for universal knowledge that is untainted by place or local interest. They can even become angry when asked to think about the global structures of power in which their knowledge work occurs.

\section{Australian social science in the global context}

Australian universities were created as a branch of the British university system, importing professors, curricula and ceremonials alike. Creating the first ones was a remarkable and even heroic thing to do in these rough and remote settler colonies, but the founders were determined to bring European culture to leaven the local lump. The relationship was beautifully expressed by the founders of the University of Sydney when they chose the motto for the university's coat of arms, Sidere Mens Eadem Mutato ('Under changed skies, the same mind'). Familiar disciplinary structures of knowledge were adopted without question. 
A century and a half later, despite a great change in scale and sophistication, the position of Australian social science in the global economy of knowledge is only slightly changed. We do now generate data locally. Apart from that, our disciplinary structure - as shown by the organisation of the Academy of the Social Sciences in Australia itself - faithfully reflects European and North American customs. Our curricula and reading lists closely resemble those of the metropole and we often use, or modestly adapt, textbooks from the metropole as the basis of our courses.

We send our promising students to the metropole for advanced training, and if they come back to Australia, having a doctorate from Cambridge, Harvard or the Sorbonne is a great career asset. We try to publish in metropolitan journalsindeed, that has become essential for serious career advancement in all the social sciences (except possibly history, and even there it is highly desirable). When we publish in local journals, our Australian data are typically framed by ideas from North American and European theorists. When we organise social science conferences in Australia, we typically bring keynote speakers from Britain and North America - rarely from Asia and almost never from Latin America or Africa. The pattern of extraversion can be traced empirically among Australian intellectual workers from a variety of institutions (Connell et al. 2005).

The condition of academic dependence on the metropole is so normal that most social scientists hardly notice it at all; it is just the way things are, like gravity. It really requires a conscious effort - of the kind made by sociologists of knowledge, standpoint epistemologists and postcolonial theorists - to see Australian social science as being in a historically produced situation that could be otherwise. Yet there have already been other possibilities.

One is given by the fact that some intellectuals in the settler population began to think in ways outside the existing metropolitan disciplinary framework - began, in fact, to produce theoretical perspectives of their own. The most illustrious of these-probably the most influential social scientist ever to emerge from Australia - was Vere Gordon Childe. He was a radical democrat who became an unorthodox Marxist. His sharp, disillusioned account of Australian workingclass politics, How labour governs, long stood as the classic text on Australian party politics (Beilharz 1995).

But it was prehistory that made Childe famous, and it is there that his power as a social theorist is best seen. Childe did some digging in sites in Scotland and Ireland; however, synthesis and interpretation on a continental, and then world, scale were his forte. I see him fundamentally as a historical sociologist who poured an immense knowledge of archaeological detail into the reconstruction of ancient social structures and dynamics of change. 
Childe's masterwork, The dawn of European civilization (1925), was a tremendous compilation of Mesolithic, Neolithic and Bronze Age data from eastern, western, southern and northern Europe, carefully sorted by region and time, out of which Childe mapped the succession and overlap of cultures, and debated the issues of dating, diffusion and autonomy from the urban civilisations of Egypt and Mesopotamia. Characteristics of his work were a massive empirical base, a vigorous classification, a concern with the cultural meanings of material remains and an attempt both to reconstruct the functioning societies that gave rise to these remains and to construct an intelligible narrative of large-scale social change.

Is there anything Australian about this? Technically, it could have been written by someone brought up in Europe, and Childe never described it as a perspective from the colonies. Yet there is something about Childe's powerful sense of space and distance, and his concern with the complexities of centre-periphery relations in the ancient world, that seems to reflect colonial experience. There is a memory of structure here that is different from the concerns with racial ancestry, with national distinctiveness or with schemes drawn from Engels, which preoccupied many of his contemporaries in European archaeology.

In his later writing, Childe produced syntheses of prehistory on a canvas broader than The dawn - an influential account of urbanism, a historically based social ontology and a sophisticated sociology of knowledge that differs markedly from the Mannheim tradition (see, for example, Childe 1949). It is thoughtprovoking that the university system in Britain did find a place for him, while the university system in Australia did not. Yet he kept an emotional connection with Australia to the end.

The other significant possibility was eliminated at the start of the university story by the adoption of a European, not just a Eurocentric, curriculum. There was already on the Australian continent an ancient civilisation with highly developed knowledge systems. Indigenous knowledge was categorically excluded from the new higher education institutions in the 1850s, and has only to a small degree, a century and a half later, been brought in.

Indigenous societies and cultures have of course provided data for a wellestablished social science in Australia, anthropology and, in the past generation, the relations between Indigenous and settler societies have also concerned history and to a lesser extent sociology. But Indigenous knowledge as a whole-involving conceptualisation, representation, observation, data, symbolic recording and practical know-how-has not yet been regarded as institutionally significant for the higher education system or for the social sciences in general (for the beginnings of recognition in one discipline, see Walter et al. 2006.) 
This has been different in other areas of the postcolonial world. One response to the disruption imposed by colonialism has been to reassert indigenous knowledge, though presenting it in new genres. This has been a particularly powerful response in Africa, where a whole literature of 'African philosophy' emerged after 1945-a project renewed under the banner of the African Renaissance' promoted by the then South African president Thabo Mbeki. Folktales, songs and poems, language forms and other elements of indigenous culture were brought together as evidence of an implicit African ontology or epistemology, which could stand as an alternative to Western knowledge (Kagamé 1956). This procedure has also been applied to generate an indigenous sociology, based on concepts drawn from the traditional poetry of Yoruba society (Akiwowo 1986).

Akiwowo's project provoked a vigorous debate (Lawuyi and Taiwo 1990) and remains controversial. I am not persuaded that it does yield a generalisable sociology, but it does produce an interesting diagnosis of the critical problems of contemporary Nigerian society, and of other countries in the region by extension-specifically, a reading of the process of change from a kinshipbased society under the impact of colonialism and the postcolonial economy. The broad question of the relationships between knowledge systems, and the alternatives to Western framings of knowledge, has been widely debated across Africa (Odora Hoppers 2002).

The African debate is dramatic, but it is not alone. There have been debates about the project of an Islamic framing for science (Ghamari 1996), and about decolonial thought in South America (Mignolo 2007). Nandy (1987) argues that Gandhi's struggle against British rule in India not only created a particularist opposition, but also confronted British power with an alternative universalism. Vinay Lal's Empire of knowledge (2002) attempts to build on this idea a broad critique of mainstream social science. There is no reason to be shy about the reach or relevance of ideas coming from subordinated or marginalised knowledge systems.

In suggesting that Akiwowo's work commands attention for the diagnosis of social change in West Africa contained in it, I wish to make a wider argument. The knowledge of social situations embedded in non-metropolitan discourses about society is knowledge of the same order - and is likely to be as detailed, subtle, grounded in experience and contestable - as metropolitan discourses about metropolitan society. But as Hountondji shows, the practical conditions under which knowledge production occurs in the periphery are very different, creating severe difficulties in circulating social knowledge that goes beyond metropolitan paradigms. 
Hountondji (1983) mounted a famous critique of the genre of 'African philosophy' as not actually indigenous knowledge. Ironically, it is a construction that reflects the coloniser's gaze. It presents African culture as static and local, in defiance of what we now know about the dynamism of African history, and it is based on a model of 'primitive unanimity' - that is, cultural consensus that is supposed (wrongly) to exist in traditional societies. We see the same patterns in traditional Australian anthropology - now fortunately changing, as shown in research like Gillian Cowlishaw's (2004) study of the hidden injuries of race.

Hountondji does not deny that indigenous knowledges survive, though he is aware that their forms and contexts change. In the volume Endogenous knowledge: Research trails (1997), he and a number of West African colleagues explore indigenous mathematics, agronomy, metallurgy and other forms of knowledge. Hountondji argues that these knowledge systems now exist as marginalised forms of knowledge within a context of extraversion. Hountondji argues, to avoid being swallowed in the global economy of knowledge, there is a need for a 'critical validation' of endogenous knowledge. This implies a search for, and affirmation of, the truth in indigenous knowledge systems. It also implies a critique of the elements of ideology that they carry - that is, a study of their limits and distortions, arising from their origins in unequal societies.

This is, doubtless, the most uncomfortable part of Hountondji's analysis. It is important, however, and necessary. If indigenous knowledge is to function in a world dominated by the knowledge systems of the colonising society, if it is to be validated and made effective, it must be capable of development and growth - and that means it must be open to critique and evaluation.

As I have argued in Southern theory (Connell 2007), and as Colin McFarlane argues in 'Crossing borders' (2006), there has to be a mutual learning process. This is not just a matter of individual learning (though that is certainly part of the process). Crucially, it is collective learning that happens at the level of whole knowledge systems.

A condition for this learning process is a certain external relationship-one of recognition. Noel Pearson (1997) has observed that 'native title' is not a concept in Aboriginal law. Nor is it a concept in European law. It is, rather, a recognition concept, which arises in the space between the two systems and allows them to interact. Specifically, this concept allows settler society's law to recognise a certain kind of rights. In his recent Rethinking social justice, Tim Rowse (2012) has given us a fascinating history of the changing forms of recognition, at least concerning the intellectuals of white settler society in Australia. 


\section{Australian neoliberalism, social science and the Asian Century story}

The policy agenda in Australian higher education since the 'Dawkins revolution' of the late 1980s has definitely been to reinforce the pattern of extraversion, not to encourage alternatives.

Policy now emphasises competition and ratings within certain measures of excellence: university league tables, citation indexes, journal rankings. These measures are centred on the global North. (Although one of the well-known global rankings of universities is produced in China, paradoxically this confirms the point: it was invented as part of an effort to find out which institutions should be used as models while the Chinese university system was built up.)

These measures of performance, and the material benefits they are increasingly linked with, produce formidable pressure to copy the elite institutions of the global North. In late 2012, then prime minister Julia Gillard announced a national policy goal to promote 10 Australian universities into the 'top 100' globally. (In mid-2013, the same government announced a funding cut for the university sector; neoliberalism has its contradictions.) Meanwhile, the commodification of higher education and the pressure to reduce costs - salaries are the largest item in university budgets - are producing online resources that allow Northern curricula to be accessed more directly. Massive open online courses (MOOCs) are the most discussed but are not the only form of this.

This policy regime for higher education is part of a much broader shift in Australian politics since the 1980s that has reshaped the public sphere on market models. First called 'economic rationalism' in Australia (Pusey 1991), and now (as is more usual internationally) 'neoliberalism', this regime is most familiar as a set of economic policies. The 'free market' is the central image, and deregulation measures that were supposed to free the markets, especially capital markets, were among the earliest and most important neoliberal policies.

Neoliberalism seeks to make existing markets wider, and to create new markets where they did not exist before. This is central to the interests of the businesspeople who fund and sustain neoliberal politics; an expanding terrain of profit-making is their definition of development. Neoliberalism pushes towards the wider, and potentially universal, commodification of services, including the realm of social reproduction. The most dramatic form is the privatisation of public assets and services, such as land and electricity. Neoliberals have, however, been quite inventive in finding other ways to commodify services, including higher education. The impact of these policies reaches far beyond economic policymaking, into the realms of everyday life and culture (Braedley and Luxton 2010). 
Neoliberal policies have not rolled back the state - indeed, the state's repressive capacity has grown - but they have gone far to halt the growth of public sector expenditure on social reproduction, translating into a real squeeze on many public services. This gradual process in the economies of the global North was packaged in a more drastic form in the structural adjustment programs of the 1980s and 1990s for countries of the global South - a logic still active, as we see in the recent devastation of Greece. In the remaining public sector, a new ethos of managerialism appears. Managers' salaries and bonuses rise, in both the private and the public sectors, to unprecedented levels. Management practice in government increasingly resembles that in corporations. An overlap of elite personnel and policymaking between the public sector and corporate capitalism develops, illustrated by the careers of top managers such as Ken Henry - not long ago secretary to the Treasury, more recently appointed director of the National Australia Bank (NAB) and the Australian Securities Exchange (ASX), and at an earlier stage of his career a representative at the rich countries' neoliberal think tank, the Organisation for Economic Cooperation and Development (OECD).

In the metropole, neoliberalism has dismantled the Keynesian welfare state, the system of regulated capitalism and state-supplied services that was dominant in the generation from 1945 to 1980 . In the global periphery, neoliberalism has dismantled the social-democratic developmentalist state and broken up the social alliances around it - most successfully in Latin America, Africa, Australia and New Zealand. Both major parties in Australia now are substantively neoliberal, and the former Gillard and current Liberal leaderships strongly so.

The forces driving neoliberalism are generally understood through a systems model of capitalism, focused on the global metropole, which is curiously reminiscent of neoclassical economics itself (Duménil and Lévy 2004; Harvey 2005). But the first country to adopt a strongly neoliberal economic regime, in the 1970s, was Chile under the Pinochet dictatorship. It was in New Zealand and Australia that labour governments in the 1980s pioneered the shift from social democracy to neoliberalism. In the 1990s, the great triumph of neoliberalism was in the former Soviet bloc. In the 2000s, neoliberalism has been working its way through the Arab world and consolidating in South Asia. Since 2000, Latin America is where the most powerful contestation of neoliberalism has emerged. Along with Samir Amin (1997), I consider that neoliberalism has as much to do with the restructuring of metropole-periphery relations as with crisis tendencies internal to the metropole.

In Australian politics, as in most parts of the global periphery, neoliberalism appears as a development agenda, a strategy for growth and prosperity. An early dramatisation of this was Paul Keating's 'banana republic' statement. A more recent version is the White Paper Australia in the Asian Century (Commonwealth of Australia 2012). In this remarkable document, neoliberal educational 
mechanisms are presented as essential preparation for 'Australia' (more exactly, Australian business elites) to tap the rivers of gold about to flow from the rising middle class of rising Asia.

Since the White Paper has been promoted as a serious contribution to thinking about Australia's future, I strongly encourage readers of this volume to read it. Chapter 6 is particularly interesting for those in the education sector. Some of the White Paper's views on inequality within Australia will also intrigue sociologists.

Commentators at the time of the White Paper's release correctly identified it as an attempt to develop a re-election narrative for the troubled Gillard government, which was long gone by the time the current book was published. As the Liberal government is even more militantly neoliberal, however, and the general approach is widespread in the Australian ruling class, the White Paper has continuing evidential value. ${ }^{2}$ John Lenarcic's (2012) tart comment about the document-A melange of bland rhetoric and generic managementspeak, leavened with policy points as mantra'-accurately indicates its representativeness.

Here are some brief reasons why it is interesting. There is little social science in the White Paper. This is not really surprising; apart from a simplified marketfriendly economics, neoliberalism generally does not have much use for social science. Disciplines such as history are put in their place by culture wars, while disciplines such as sociology are increasingly residualised, given contracts to research the lives of groups considered market failures.

Australia does in fact have highly knowledgeable social scientists who have done rich and detailed research in Southeast, South and East Asian societies. Practically none of their research appears in the references of the Asian Century White Paper, and the text shows little sign of this knowledge base. Its account of 'Asia' is a breathless story of benevolent governments and economic booms caused by deregulation and free trade. To the extent that the White Paper has any ideas about the nature of societies in the region, they are schematic and overgeneralised, especially the idea that their most important feature will be an ever-expanding 'middle class' with ever-expanding consumption demands.

What was considered important-indeed, what provided the framing ideas for the White Paper-was the output of corporate ideologues, especially management consultants. A number of management consultancies and corporate research units are specifically cited as sources in the White Paper-among them Boston Consulting, Deloitte Access Economics, HSBC, McKinsey, ANZ,

2 The Liberal government's continued commitment to an engagement with Asia, and the government's emphasis on economic imperatives, is discussed in Chapter 1 of this volume. 
PricewaterhouseCoopers and Goldman Sachs. More generally, the document is framed in their style and within their characteristic approach to the world. Management consulting is an industry whose elite has now acquired the role of organic intellectuals to corporate business, increasingly providing the formulaic common sense of the public realm - the language in which politics and journalism, as well as business, speak. Collectively, management consultants understand 'Asia' as a gigantic, swelling market for the products and services of transnational corporations.

The main concern of the White Paper is that Australian corporations should put their foot on as large a share of this market as possible, and that Australian governments should organise their policies to facilitate this. I am putting it bluntly, but truly, the White Paper's main line is as blunt as this. It ends with these inspiring words:

Right across our nation - in governments, businesses, unions, educational and cultural institutions and broad community groups - we need to become even more innovative, efficient and adaptable. All of us will need to work smarter to maximise prosperity. (Commonwealth of Australia 2012: 272)

As a blueprint for a rich country's future relations with poorer countries in the neighbourhood, the White Paper is breathtakingly cynical. But it is strictly in line with the main tendency of neoliberalism in the global periphery: to see the path of development in complete integration into global markets, via a search for comparative advantage. In recent decades, Australia's comparative advantage is mainly found in the minerals extracted by transnational mining corporations. In pursuit of that advantage, manufacturing and public infrastructure have been run down.

To do it justice, the White Paper is trying to think beyond coal and iron ore. In his role as an economic advisor to government, its principal author, Ken Henry, was a proponent of a serious tax on mining profits. In his role as a director of the NAB, he has a fiduciary duty to foster banking profits, and as a director of the ASX his responsibility is to expand the corporate economy from which come stock exchange transactions. Framed with ideas from that corporate world, the White Paper cannot think beyond the neoliberal logic of commodification and the restless search for advantage in global markets.

As a guide to the future of Australian social science, this is bleak indeed. Basically, it suggests social science is irrelevant. It encourages neither serious thought about Australian society nor engagement with the multiple intellectual worlds beyond the withered neoliberal imagination. 


\section{Global social science and Australian society}

To rethink Australian society in a world context, an essential starting point is to recognise the wealth of social thought in the global South, existing in many genres and going through its own development. In this chapter, I can only gesture towards this wealth.

Around the colonial encounter itself, intellectuals of colonised societies developed the analysis and critique of colonialism and the study of its impact. Pioneering figures here included al-Afghani, whose famous Refutation of the materialists (1968 [1881]), along with his journalism, contains a cultural critique of imperialism from an Islamic standpoint, and elaborates an alternative strategy of modernisation. At the other end of the Islamic world, in the Dutch East Indies, in the early years of the twentieth century, Kartini wove together a critique of the colonial regime with a critique of local patriarchy into a strategy for the educational advancement of Javanese women (2014). José Rizal, the central intellectual figure in the Philippine struggle for independence, wrote wideranging critiques of colonial society in the form of two famous novels, Noli Me Tangere and El Filibusterismo. Sun Yat-sen, known as the first president of the Republic of China, produced sharp social analysis in his late essays San Min Chu I (1975), with incisive observations about cultural hybridisation as well as economic and technological development. Perhaps the most striking example was Solomon Plaatje's Native life in South Africa (1982). Plaatje, the secretary of the organisation that was forerunner to the African National Congress (ANC), studied the impact of the Natives Land Act of 1913. He travelled the country doing fieldwork, and on this basis told the story of indigenous families displaced from their land by this racial enclosure Act. He wove this together with analysis of the colonial state, the attitudes of settler society and the relevant political history.

Following on from this, intellectuals of the South have made analyses of the societies produced by colonialism and the changing forms of their relationship with the metropole. Pride of place goes to the rich Latin American literature on dependence and development. Raúl Prebisch's The economic development of Latin America and its principal problems (1950) and Octavio Paz's The labyrinth of solitude (1990), first published in the same year as Prebisch's remarkable work, represent this moment on the economic and cultural sides respectively. They were followed by a growing literature of political economy and sociology, in which Cardoso and Faletto's Dependency and development in Latin America (1979), a vast synthesis of historical sociology, is a high point.

Ashis Nandy (2003) centres his critique of contemporary Indian society on the modernising state - which was split, but not dismantled, at independence in 1947 - and the secularised middle classes whose interests it mainly represents. 
Such analyses are not easily confined within one academic discipline. Nandy weaves together sociological, psychological, historical, literary and media analysis (see An ambiguous journey to the city, 2001). Veena Das's Critical events (1995) moves far beyond her discipline of anthropology, and Bina Agarwal's tremendous A field of one's own (1994) goes far beyond her discipline of economics. Ali Shariati (1986) in Iran worked on the basis of an intimate connection between theology and the social sciences. So does Abdolkarim Sorush in political theories developed in the period since the Islamic revolution of 1979 (Ghamari-Tabrizi 2004).

These forms of knowledge are not utterly separated from knowledge systems in the metropole. Indeed, most of the intellectuals just mentioned have made a critical appropriation of metropolitan knowledge systems, combining them in new ways with the experience and knowledges of the periphery. Thus, Linda Tuhiwai Smith has adapted social research procedures, especially those of qualitative social science, and combined them with Maori culture and political experience in her influential Decolonizing methodologies (2012). The point is not an absolute separation of Southern knowledge systems from Northern; it is, rather, to achieve the recognition and mutual learning described earlier.

For that, our current main task is to recognise and engage with the wealth of social thought around the global South, despite the pressure of the global economy of knowledge to focus on the thought of the North. Aids to this task exist. There are conceptual statements and reviews of non-metropolitan social thought, such as Farid Alatas's Alternative discourses in Asian social science (2006), and Chilla Bulbeck's Re-orienting Western feminisms (1998). There are case studies such as Wiebke Keim's Vermessene Disziplin (2008) and, in a different register, Lydia Liu et al.'s The birth of Chinese feminism (2013). Attempts are being made to decolonise social sciences and even philosophy in the global North (Go 2013; Gutiérrez Rodríguez et al. 2010; Harding 2008). There are compilations and surveys such as Sujata Patel's International handbook of diverse sociological traditions (2010). This is just a beginning with the resources available; many more can be found via institutions such as the Council for the Development of Social Science Research in Africa (CODESRIA) and the Latin American Council of Social Sciences (CLACSO). All of these texts concern a shift of intellectual authority, actual or potential, to the global periphery - and that provides a new context for understanding Australian society.

Since most of the work remains to be done, I cannot summarise conclusions here, but I will conclude by suggesting some of the dimensions of the rethinking possible. 
First is the task of rethinking the nature of Australian society. Much of our work in social science presumes that it is continuous with European or North American society, so we can apply Bourdieu or Butler or Foucault without hesitation. Learning social perspectives from the global South will encourage us to think about the specificities of a settler-colonial society, a dependent primaryexporting economy, a dependent or satellite polity, and a Southeast Asian, Oceanic and Antarctic environment - with tensions and complexities in all the relationships implied by those categories. Our own neighbourhood provides interesting models of thought about, for instance, society in the context of the Pacific Ocean (Hau'ofa 2008).

Second is to grapple with the issue that Aboriginal intellectuals and Aboriginal politics persistently point out: the land. As the work of Bina Agarwal (1994) in India and João Maia (2011) in Brazil shows, the significance of land in social relations is not a uniquely Australian concern; indeed, it is a central issue in colonisation generally. A society formed in and through the violent taking of land from indigenous communities embeds a structural violence. This continues to surface in Australian society in important ways - most troublingly, at present, in the persistence of racism and the toxic politics of the 'intervention' and 'border protection'. The land is also reasserting itself in the form of environmental issues, which will certainly become more important to Australian social science.

A third dimension concerns the practice of social science in Australia: curriculum and teaching, research agendas and methods, and career structures. Paying attention to the conditions of intellectual work in other parts of the periphery (such as those described by Mkandawire 2005) will be illuminating. The postcolonial world offers many alternatives, good and bad, to the patterns engraved in the Northern-centred global economy of knowledge. Under the pressures of neoliberal management, however, it involves effort and cost to explore these alternatives. Here, social science organisations, including the Academy of Social Sciences in Australia, could do much to support new directions of practice and to legitimate Australian participation in the decentring of world social science.

A fourth dimension concerns the global division of labour in the mainstream economy of knowledge that locates the formation of theory (including methodology) basically in the metropole. In fact, there is a lively theoretical dimension in intellectual production in the periphery, though it is greatly underrecognised except in the 'indigenous knowledge' debates. Australian social science can, in principle, be greatly enriched by opening up to new resources of concepts and methods. 
Finally, a deeper connection with social thought around the global periphery has strategic potential for the social sciences in Australia. I have mentioned the tendency under neoliberalism for the social sciences to become residualised. It is already clear that social science has a declining role in Australian public policymaking; the Asian Century White Paper is only one among many examples of this. A collective learning process that encounters the social experience and intellectual practice of the rest of the periphery will, among other things, offer multiple new models for the engagement of social science in the practical world.

In his book The redress of poetry, the great poet of postcolonial Ireland Seamus Heaney remarks that '[t]he poet must in some sense set the world free to have a new go at its business'. I think that is one of the roles of social science, too. In Australia, the real encounter with the social world of the South around us, and not just the social world of the global North, is critical to making it happen.

\section{References}

Agarwal, Bina. 1994. A field of one's own: Gender and land rights in South Asia. Cambridge: Cambridge University Press.

Akiwowo, Akinsola A. 1986. Contributions to the sociology of knowledge from an African oral poetry. International Sociology 1(4): 343-58.

Al-Afghani, Sayyid Jamal ad-Din. 1968 [1881]. An Islamic response to imperialism: Political and religious writings of Sayyid Jamal ad-Din 'al-Afghani'. Trans Nikki R. Keddie and Hamid Algar. Berkeley: University of California Press.

Alatas, Syed Farid. 2006. Alternative discourses in Asian social science: Responses to Eurocentrism. New Delhi: Sage.

Amin, Samir. 1997. Capitalism in the age of globalization: The management of contemporary society. London: Zed Books.

Beilharz, Peter. 1995. Vere Gordon Childe and social theory. In Peter Gathercole, T.H. Irving and Gregory Melleuish, eds. Childe and Australia: Archaeology, politics and ideas. Brisbane: University of Queensland Press.

Bhambra, Gurminder K. 2007. Sociology and postcolonialism: Another 'missing' revolution? Sociology 41(5): 871-84.

Braedley, Susan and Luxton, Meg. eds. 2010. Neoliberalism and everyday life. Montreal \& Kingston: McGill-Queen's University Press. 
Bulbeck, Chilla. 1998. Re-orienting Western feminisms: Women's diversity in a postcolonial world. Cambridge: Cambridge University Press.

Cardoso, Fernando Henrique and Faletto, Enzo. 1979 [1971]. Dependency and development in Latin America. Berkeley: University of California Press.

Chakrabarty, Dipesh. 2000. Provincializing Europe: Postcolonial thought and historical difference. Princeton, NJ: Princeton University Press.

Childe, Vere Gordon. 1925. The dawn of European civilization. London: Kegan Paul, Trench, Trubner \& Co.

Childe, Vere Gordon. 1949. Social worlds of knowledge. L.T. Hobhouse Memorial Trust Lecture No. 19. London: Oxford University Press.

Commonwealth of Australia. 2012. Australia in the Asian Century. White Paper. Canberra: Commonwealth of Australia. URL: pandora.nla.gov. $\mathrm{au} / \mathrm{pan} / 133850 / 20130914-0122 /$ asiancentury.dpmc.gov.au/index.html. Consulted 15 March 2015.

Connell, Raewyn. 2007. Southern theory: The global dynamics of knowledge in social science. Sydney: Allen \& Unwin.

Connell, Raewyn. 2011. Confronting equality: Gender, knowledge and global change. Sydney: Allen \& Unwin.

Connell, Raewyn, Wood, Julian and Crawford, June. 2005. The global connections of intellectual workers: An Australian study. International Sociology 20(1): 5-26.

Cowlishaw, Gillian. 2004. Blackfellas, whitefellas and the hidden injuries of race. Oxford: Blackwell.

Das, Veena. 1995. Critical events: An anthropological perspective on contemporary India. New Delhi: Oxford University Press.

Domingues, José Maurício. 2008. Latin America and contemporary modernity: A sociological interpretation. New York: Routledge.

Duménil, Gérard and Lévy, Dominique. 2004. Capital resurgent: Roots of the neoliberal revolution. Cambridge, MA: Harvard University Press.

Foucault, Michel. 1977. Discipline and punish: The birth of the prison. New York: Pantheon.

Ghamari-Tabrizi, Behrooz. 1996. Is Islamic science possible? Social Epistemology 10(3-4): 317-30. 
Ghamari-Tabrizi, Behrooz. 2004. Contentious public religion: Two conceptions of Islam in revolutionary Iran. International Sociology 19(4): 504-23.

Go, Julian. 2013. For a postcolonial sociology. Theory and Society 42(1): 25-55.

Gutiérrez Rodríguez, Encarnación, Boatcă, Manuela and Costa, Sérgio. eds. 2010. Decolonizing European sociology: Transdisciplinary approaches. Farnham, UK, and Burlington, VT: Ashgate.

Harding, Sandra. 2008. Sciences from below: Feminisms, postcolonialities, and modernities. Durham, NC: Duke University Press.

Harvey, David. 2005. A brief history of neoliberalism. Oxford: Oxford University Press.

Hau'ofa, Epeli. 2008. We are the ocean. Honolulu: University of Hawai'i Press.

Heaney, Seamus. 1995. The redress of poetry. New York: Farrar, Straus \& Giroux.

Hountondji, Paulin J. 1983 [1976]. African philosophy: Myth and reality. Trans Henri Evans and Jonathan Rée. London: Hutchinson.

Hountondji, Paulin. ed. 1997. Endogenous knowledge: Research trails. Dakar: CODESRIA.

Kagamé, Alexis. 1956. La philosophie bantu-rwandaise de l'être. Brussels: Académie royale des sciences coloniales.

Kartini. 2014. Kartini: The complete writings 1898-1904. Edited and translated by Joost Coté. Melbourne: Monash University Publishing.

Keim, Wiebke. 2008. Vermessene disziplin: Zum konterhegemonialen potential afrikanischer und lateinamerikanischer soziologien. Bielefeld: Transcript Verlag.

Lal, Vinay. 2002. Empire of knowledge: Culture and plurality in the global economy. London: Pluto.

Lawuyi, O.B. and Taiwo, Olufemi. 1990. Towards an African sociological tradition: A rejoinder to Akiwowo and Makinde. International Sociology 5(1): $57-73$.

Lenarcic, John. 2012. Asian Century White Paper. The Conversation 28 October. URL: theconversation.edu.au/asian-century-white-paperexperts-respond-10370. Consulted 20 March 2015. 
Liu, Lydia H., Karl, Rebecca E. and Ko, Dorothy. eds. 2013. The birth of Chinese feminism: Essential texts in transnational theory. New York: Columbia University Press.

Lukács, Gyorgy. 1971 [1923]. History and class consciousness: Studies in Marxist dialectics. London: Merlin Press.

McFarlane, Colin. 2006. Crossing borders: Development, learning and the North-South divide. Third World Quarterly 27(8): 1413-37.

Maia, João Marcelo Ehlert. 2011. Space, social theory and peripheral imagination: Brazilian intellectual history and de-colonial debates. International Sociology 26(3): 392-407.

Mannheim, Karl. 1985 [1929]. Ideology and utopia: An introduction to the sociology of knowledge. San Diego: Harcourt Brace Jovanovich.

Meekosha, Helen. 2011. Decolonizing disability: Thinking and acting globally. Disability and Society 26(6): 667-81.

Mignolo, Walter D. 2005. The idea of Latin America. Malden, Mass.: Blackwell.

Mignolo, Walter D. 2007. Delinking: The rhetoric of modernity, the logic of coloniality and the grammar of de-coloniality. Cultural Studies 21(2-3): 449-514.

Mkandawire, Thandika. ed. 2005. African intellectuals: Rethinking politics, language, gender and development. Dakar and London: CODESRIA \& Zed Books.

Montero, Maritza. 2007. The political psychology of liberation: From politics to ethics and back. Political Psychology 28(5): 517-33.

Nandy, Ashis. 1987. Traditions, tyranny and utopias: Essays in the politics of awareness. Delhi: Oxford University Press.

Nandy, Ashis. 2001. An ambiguous journey to the city: The village and the other odd ruins of the self in the Indian imagination. New Delhi: Oxford University Press.

Nandy, Ashis. 2003. The romance of the state: And the fate of dissent in the tropics. New Delhi: Oxford University Press.

Odora Hoppers, Catherine A. ed. 2002. Indigenous knowledge and the integration of knowledge systems: Towards a philosophy of articulation. Claremont, South Africa: New Africa Books. 
Patel, Sujata. 2010. International handbook of diverse sociological traditions. London: Sage.

Paz, Octavio. 1990 [1950]. The labyrinth of solitude. Enlarged edn. London: Penguin.

Pearson, Noel. 1997. The concept of native title at common law. In Galarrwuy Yunupingu, ed. Our land is our life. Brisbane: University of Queensland Press.

Plaatje, Solomon T. 1982 [1916]. Native life in South Africa: Before and since the European war and the Boer rebellion. New edn. Braamfontein: Ravan Press.

Prebisch, Raúl. 1950. The economic development of Latin America and its principal problems. New York: United Nations Department of Economic Affairs.

Pusey, Michael. 1991. Economic rationalism in Canberra: A nation-building state changes its mind. London: Cambridge University Press.

Quijano, Aníbal. 2000. Coloniality of power and Eurocentrism in Latin America. International Sociology 15(2): 215-32.

Reuter, Julia and Villa, Paula-Irene. eds. 2010. Postkoloniale soziologie: Empirische befunde, theoretische anschlüsse, politische intervention. Bielefeld: Transcript.

Rowse, Tim. 2012. Rethinking social justice: From 'peoples' to 'populations'. Canberra: Aboriginal Studies Press.

Said, Edward W. 1978. Orientalism. London: Routledge \& Kegan Paul.

Shariati, Ali. 1986. What is to be done? The enlightened thinkers and an Islamic renaissance. Ed. Farhang Rajaee. Houston: Institute for Research and Islamic Studies.

Smith, Dorothy. 1990. The conceptual practices of power: A feminist sociology of knowledge. Boston: Northeastern University Press.

Smith, Linda Tuhiwai. 2012. Decolonizing methodologies: Research and indigenous peoples. 2nd edn. London: Zed Books.

Sun Yat-sen. 1975 [1927]. San Min Chu I: The three principles of the people. Trans. Frank W. Price, ed. L.T. Chen. New York: Da Capo Press.

Walter, Maggie, Pyett, Priscilla, Tyler, Bill and Vanderwyk, Annie. eds. 2006. Beyond the margins/beyond marginality. Journal of Sociology Special Issue 42(4): 341-45. 
This text is taken from The Social Sciences in the Asian Century, edited by Carol Johnson, Vera Mackie and Tessa Morris-Suzuki, published 2015 by ANU Press, The Australian National University, Canberra, Australia. 